\title{
Ringlegged Earwig, Euborellia annulipes (Lucas) (Insecta: Dermaptera: Carcinophoridae) ${ }^{1}$
}

John L. Capinera²

\section{Introduction}

This is the most common pest earwig in Florida, though it rarely builds to very high numbers. It is mostly known as a nuisance, and the small amount of plant feeding injury it causes likely is offset by its beneficial predatory habits.

\section{Distribution}

First found in the United States in 1884, the ringlegged earwig now is widespread in the southern states and in Hawaii. It is also known from many northern states, and from southern Canada. It likely is of European origin, and has been transported to many other areas of the world, including both tropical and temperate climates.

\section{Description and Life Cycle}

Under greenhouse conditions in Ohio, three generations a year were observed, one each in the spring, autumn, and winter months. A complete generation can be completed in 61 days (Klostermeyer 1942). Thus, under field conditions, it seem probable that at least two generations occur, one each in spring and autumn, at least in warm climates. In Illinois, adults can be found throughout the year except during winter when adults seek shelter deep in the soil.

\section{Egg}

The eggs are nearly spherical in shape when first deposited, measuring about $0.75 \mathrm{~mm}$ in diameter. As the embryos develop, however, the eggs becomes more elliptical in shape, attaining a length of about $1.25 \mathrm{~mm}$. The eggs are creamy white initially, becoming brown as the embryos develop. Females deposit one to seven clutches of eggs with a mean clutch size of about 50 eggs. Total egg production is estimated at 100 to 200 eggs. Duration of the egg stage is six to 17 days.

\section{Nymph}

The nymphs greatly resemble the adults in form, differing primarily in size. Wingpads are absent. All instars have 10 abdominal segments. The head and abdomen are dark brown. The pronotum is

1. This document is EENY-088, one of a series of Featured Creatures from the Entomology and Nematology Department, Florida Cooperative Extension Service, Institute of Food and Agricultural Sciences, University of Florida. Published: June 1999. Reviewed: May 2003. This document is also available on Featured Creatures Website at http://creatures.ifas.ufl.edu. Please visit the EDIS Website at http://edis.ifas.ufl.edu. Additional information on these organisms, including many color photographs, is available at the Entomology and Nematology Department Website at http://entnemdept.ifas.ufl.edu/.

2. John L. Capinera, professor/chairman, Entomology and Nematology Department, Institute of Food and Agricultural Sciences, University of Florida, Gainesville, FL 32611.

The Institute of Food and Agricultural Sciences (IFAS) is an Equal Employment Opportunity - Affirmative Action Employer authorized to provide research, educational information and other services only to individuals and institutions that function without regard to race, creed, color, religion, age, disability, sex, sexual orientation, marital status, national origin, political opinions or affiliations. For information on obtaining other extension publications, contact your county Cooperative Extension Service office. Florida Cooperative Extension Service / Institute of Food and Agricultural Sciences / University of Florida / Larry R. Arrington, Interim Dean 


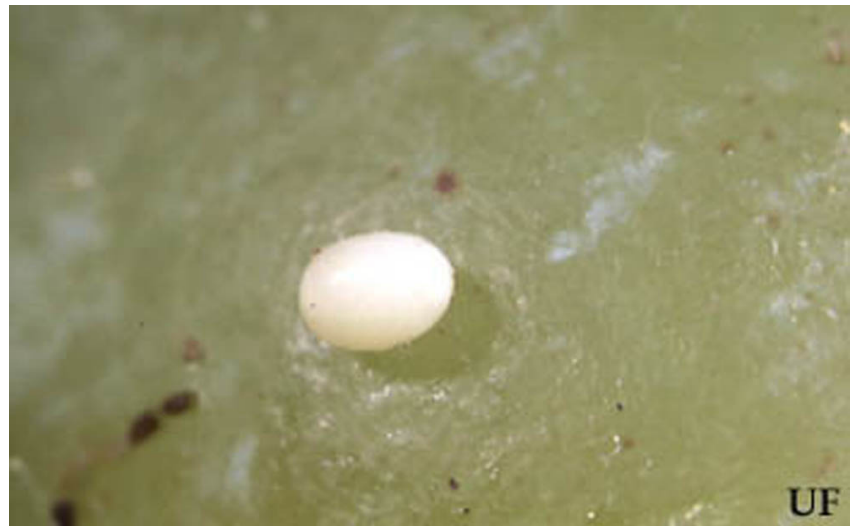

Figure 1. Egg of the ringlegged earwig, Euborellia annulipes (Lucas). Credits: Paul. M. Choate, University of Florida

considerably lighter in color, usually grayish or yellowish brown. The legs are whitish, with a dark ring around the femur. The cerci are moderately long, and not strongly curved. Normally, five instars are found, but six are observed occasionally. Instars are difficult to distinguish and no single character is completely diagnostic. The number of antennal segments is most useful, though this is mostly effective among the early instars. The number of antennal segments is about 8, 11, 13, $14-15,15-16$, and $14-17$ in instars one to six.

Head capsule width is 0.62-0.75, 0.70-0.91, $0.83-1.09,1.04-1.56,1.22-1.56$, and $1.40-1.72 \mathrm{~mm}$ for instars 1 to 6 , respectively.

Body length is 3.0-4.7, 3.9-6.9, 5.7-7.7, 6.7-10.8, 8.7-13.2, and 9.8-12.9 $\mathrm{mm}$, respectively, for instars one to six.

When reared at 21 to $23^{\circ} \mathrm{C}$, Bharadwaj (1966) reported mean development times of 11.8, 10.6, 13.4, 16.3, 20.1, and 27.0 days for instars one to six, respectively, for a total of about 99 days.

\section{Adult}

The adults are dark brown in color, and wingless. They measure 12 to $16 \mathrm{~mm}$ in length, with females averaging slightly larger than males. The legs are pale, usually with a dark band around the middle of the femur, and often tibia, of each leg. Adults generally bear 16 antennal segments. The leg bands are the basis for the common name, and are readily apparent. The cerci of the adults can be used to distinguish the sexes. In the male the cerci are more curved, with the right branch of the forceps turned sharply inward at the tip. The males also possess 10 abdominal segments, whereas females possess eight segments.

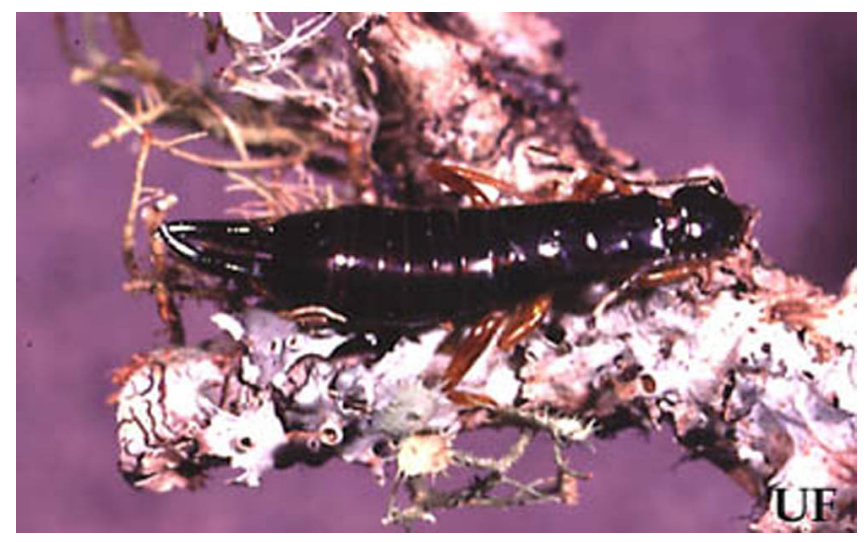

Figure 2. Adult ringlegged earwig, Euborellia annulipes (Lucas). Credits: Paul. M. Choate, University of Florida

The ringlegged earwigs should not be confused with the common winged Doru spp. earwigs (Dermaptera: Forficulidae) which also occur frequently in Florida. Doru earwings have wings, including tan colored bands on the prononum and front wings. They are important caterpillar predators. Hoffman (1987) provides a key to eastern earwigs which contains the Florida species.

Earwigs are nocturnal. Mating occurs one to two days after attainment of the adult stage, and oviposition commences about 10 to 15 days after mating. The adults construct a small cell in the soil in which eggs are deposited. The female drives the male from the oviposition chamber before eggs are produced. The female protects the egg clutch from mites, fungi, and intruders, cleaning and relocating them if necessary. Maternal care decreases soon after nymphs hatch, disappearing after about 10 days. The female will not tolerate the presence of her progeny once she begins production of a subsequent egg clutch. Adults are long-lived, and capable of living over 200 days.

\section{Host Plants}

The ringlegged earwig is omnivorous in its feeding habits, taking both plant and animal material readily. It occurs as a minor nuisance in southern vegetable gardens and in greenhouses where it will nibble on succulent plants such as lettuce. It is also 


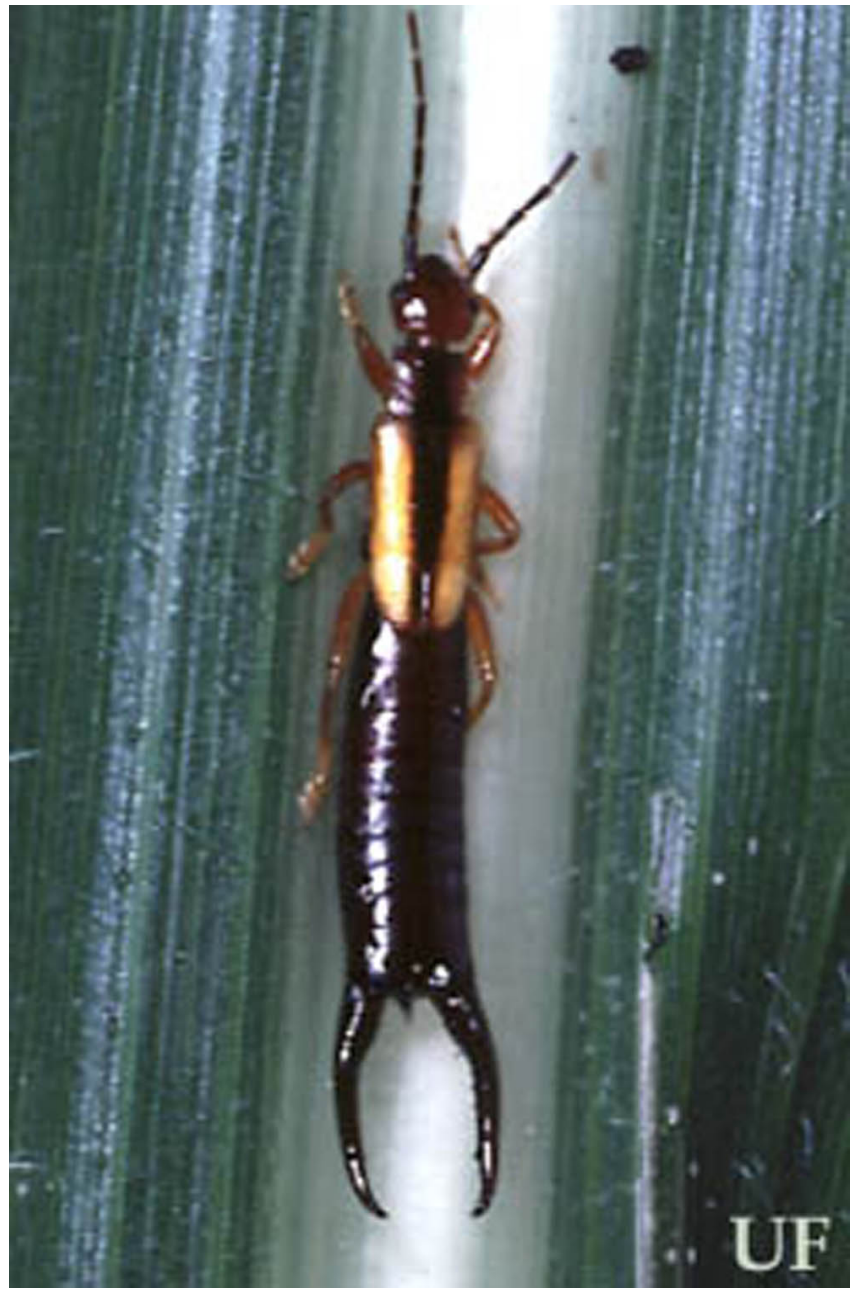

Figure 3. Adult earwig, Doru sp. Credits: Paul. M. Choate, University of Florida

documented to feed on the roots or tubers of radish, potato, and sweetpotato, and the pods of peanuts, though this is normally of little consequence. The ringlegged earwig is a voracious predator of insects and sowbugs, and this predatory behavior probably offsets the small amount of damage done to plants. It is also highly cannibalistic.

\section{Damage}

These earwigs cause little direct injury to growing vegetable crops, but can feed on both the aboveground and belowground portions of plants. More commonly, they serve as a contaminant of produce, sometimes defecating on leafy green vegetables. These earwigs are important insect predators, and are documented to feed on such diverse prey as caterpillars, beetle larvae, and leafhoppers. Unfortunately, there seems to be no quantitative data on their relative importance.

\section{Natural Enemies}

The natural enemies of ringlegged earwig seem to be undocumented, though they are likely about the same as those attacking the European earwig, Forficula auricularia Linneaus (Dermaptera: Forficulidae), consisting principally of parasitic flies (Diptera: Tachinidae) and fungi. Cannibalism of eggs and nymphs by adults is an important mortality factor.

\section{Management}

These earwigs rarely warrant suppression, but are easily killed by most residual insecticides. They also take bait formulations consisting of wheat bran, molasses, and toxicant, as well as many other baits (Neiswander 1944). Baits sold for control of mole crickets will also kill earwigs.

\section{Selected References}

Bharadwaj, R.K. 1966. Observation on the bionomics of Euboriellia annulipes (Dermaptera: Labiduridae). Annals of the Entomological Society of America 59:441-450.

Choate, P. M. 2001. The earwigs (Dermaptera) of Florida and eastern United States. http://entnemdept.ifas.ufl.edu/choate/dermaptera.pdf (13 November 2002).

Hoffman, K.M. 1987. Earwigs (Dermaptera) of South Carolina, with a key to the eastern North American Species and a checklist of North American Fauna. Proceedings of the Entomological Society of Washington 89:1-14.

Klostermeyer, E.C. 1942. The life history and habits of the ring-legged earwig, Euboriella annulipes (Lucus) (Order Dermaptera). Journal of the Kansas Entomological Society 15:13-18.

Koehler, P.G., D.E.Short and T.R. Fasulo. 1998. Pests In and Around the Home. UF/IFAS, SW-126.

Neiswander, C.R. 1944. The ring-legged earwig, Euboriela annulipes (Lucas). Ohio Agricultural Experiment Station Bulletin 648. 14 pp. 